NBER WORKING PAPER SERIES

\title{
"BASKET" CASES: INTERNATIONAL JOINT VENTURES AFTER THE \\ TAX REFORM ACT OF 1986
}

Mihir A. Desai

James R. Hines, Jr.

Working Paper 5755

\section{NATIONAL BUREAU OF ECONOMIC RESEARCH 1050 Massachusetts Avenue \\ Cambridge, MA 02138 \\ September 1996}

We thank Richard Caves, Dennis Encarnation, Kevin Hassett, and Bernard Yeung for helpful comments on an earlier draft, and the National Science Foundation for financial support (Grant No. SES-9209373). This paper is part of NBER's research program in Public Economics. Any opinions expressed are those of the authors and not those of the National Bureau of Economic Research.

(C) 1996 by Mihir A. Desai and James R. Hines, Jr. All rights reserved. Short sections of text, not to exceed two paragraphs, may be quoted without explicit permission provided that full credit, including $(\mathcal{O}$ notice, is given to the source. 
NBER Working Paper 5755

September 1996

\title{
"BASKET" CASES: INTERNATIONAL JOINT VENTURES AFTER THE \\ TAX REFORM ACT OF 1986
}

\begin{abstract}
This paper examines the impact of the Tax Reform Act of 1986 (TRA) on international joint ventures by American firms. The evidence suggests that the TRA had a significant effect on the organizational form of U.S. business activity abroad. The TRA mandates the use of separate "baskets" in calculating foreign tax credits on income received from foreign corporations owned $50 \%$ or less by Americans. This limitation on worldwide averaging greatly reduces the attractiveness of joint ventures to American investors, particularly ventures in low-tax foreign countries. Aggregate data indicate that U.S. participation in international joint ventures fell sharply after 1986. The decline in U.S. joint venture activity is most pronounced in low-tax countries, which is consistent with the incentives created by the TRA. Moreover, joint ventures in low-tax countries use more debt and pay greater royalties to their U.S. parents after 1986, which reflects their incentives to economize on dividend payments.
\end{abstract}

Mihir A. Desai

Program in Political Economy Littauer Center, Second Floor Harvard University

Cambridge, MA 02138

mdesai@ksg1.harvard.edu
James R. Hines, Jr.

John F. Kennedy School of Government Harvard University 79 John F. Kennedy Street Cambridge, MA 02138 and NBER jamesh@ksg1.harvard.edu 


\section{Introduction.}

There is growing evidence of the importance of organizational form to business operations and of the influence of government policies on the forms that businesses take. Tax systems often give firms incentives to adopt certain organizational forms at the expense of others. For example, the U.S. corporate income tax must be paid by corporations but not by unincorporated businesses. This and other U.S. tax provisions appear to influence the organization of domestic business, 'though their effect on international business is still poorly understood.

The purpose of this paper is to examine the effect of 1986 U.S. tax legislation that imposes significant costs on international joint venture operations. Since the 1986 law raises the cost of U.S. participation in joint ventures in some countries more than it does in others, it is possible to use the country-level pattern of responses after 1986 to infer the degree to which firms substitute one organizational form for another. The results indicate that passage of the TRA coincides with a dramatic shift in the level and pattern of U.S. participation in international joint ventures, suggesting that the tax act may be responsible for significantly reduced American joint venture activity. The character of joint venture activity changes at the same time and in a way that is consistent with the incentives created by the legislation.

Until the 1980s, there were increasing numbers of international joint ventures between American multinational firms and locally-owned foreign firms. Such arrangements offer American firms the prospect of generating significant profits while obtaining market footholds and avoiding some of the local market risks associated with wholly-owned ventures. International joint ventures are particularly popular in high-technology industries in which different firms may have proprietary assets - such as patents, trademarks, and know-how - that are complementary in production. Joint venture activity is limited to a significant degree by the moral hazard costs inherent in organizational

\footnotetext{
'See the evidence presented in Gordon and MacKie-Mason (1990, 1994) and Gentry (1994).
} 
structures with split ownership. In spite of this limitation, joint ventures are widely viewed as the cutting edge of international business. ${ }^{2}$

The U.S. Tax Reform Act of 1986 (TRA) introduced a number of important changes intended to rationalize taxation in the United States and to reduce incentives for inefficient taxavoiding activities. One of the provisions of the TRA changed the taxation of dividends received from international joint ventures owned between $10 \%$ and $50 \%$ by Americans. This reform increases the tax cost of undertaking joint ventures, the effect being most pronounced for joint ventures in countries with low tax rates.

The joint venture provisions of the TRA had their origin in a much more sweeping proposal advanced by President Reagan in 1985. In The President's tax reform proposals (1985), he urged Congress to change the calculation of foreign tax credit limits by replacing the existing system, based on worldwide averages, with one that would calculate limits separately for each foreign country. Such a change would reduce the foreign tax credits that American multinational firms could claim, thereby increasing their U.S. tax liabilities. By the time that Congress passed the Tax Reform Act of 1986 , this provision was removed due to its perceived arbitrariness and amid concern over its potential impact on American competitiveness abroad.

Congress decided to remove worldwide averaging only for categories of foreign income that it segregates into separate "baskets." The TRA creates a separate "basket" for dividends received from each so-called "10-50 corporation" - foreign corporations owned between $10 \%$ and $50 \%$ by Americans. By segregating income in this way, the TRA greatly reduces the attractiveness to American investors of minority participation in internationl joint ventures, particularly those in low-

\footnotetext{
${ }^{2}$ For example, Bleeke and Ernst (1993, p. 269) offer that, “Organizations of the future have to seek partners who can share costs and swap skills and access to markets. In the fluid global marketplace, it is no longer possible or desirable for a single organization to be entirely self-sufficient. Collaboration is the value of the future. Alliances are the structure of the future."
} 
tax foreign countries. Since majority-owned ventures were not similarly affected by the TRA, American multinationals with minority-owned joint ventures in low-tax countries face strong incentives after 1986 either to become majority owners of the ventures or to reduce or liquidate their minority positions.

The evidence suggests that the TRA had a significant effect on the organizational form of U.S. business activity abroad. Aggregate time series data reveal that American participation in minority joint ventures declined significantly after 1986. The country-level pattern is consistent with the incentives created by the TRA: joint venture activity fell most sharply in countries with low tax rates. Furthermore, the character of joint venture activity changed. By segregating dividends received from "10-50 corporations" into separate "baskets," the TRA raises the cost of equity financing of joint ventures, and thereby increases the attractiveness of joint ventures that economize on dividend payments to American partners. The evidence indicates that joint ventures in which American firms participate after 1986 exhibit higher debt/asset ratios and greater proclivity to pay royalties to American partners than before 1986 , the difference being significantly more pronounced in low-tax countries than in high-tax countries. Assuming that royalty payments represent compensation for transfers of technology, the "basket" provisions of the TRA appear to influence the pattern of technology transfer by U.S. multinationals.

The joint venture provisions of the TRA have greater impact on operations in low-tax foreign countries than those in high-tax foreign countries, which makes it possible to identify the impact of the 1986 Act by relating changes in business activity after 1986 to local tax rates. Unfortunately, this procedure does not clearly distinguish different ways in which American firms respond to the TRA. Possible responses include converting joint ventures to majority-owned affiliates, relocating joint ventures to high-tax countries, changing the capital structures and payout policies of existing joint ventures, and avoiding altogether some otherwise-attractive joint venture 
opportunities. The available evidence does not distinguish between these responses but does document the sensitivity of organizational form to tax considerations. The evident responsiveness of international joint venture activity to the 1986 tax change is consistent with a growing body of literature that documents the effect of tax policies on the location and behavior of multinational firms ${ }^{3}$

Section 2 of the paper reviews the determinants of international joint venture activity, presents estimates of the factors that influence the location of American joint ventures in 1982, and traces the decline of U.S. international joint ventures after 1986. Section 3 analyzes the effect of the TRA on the incentives for American firms to form international joint ventures. Section 4 presents regression results describing the effect of local tax rates on American participation in joint ventures before and after the 1986 tax change. Section 5 is the conclusion.

\section{International Joint Venture Activity.}

In undertaking joint ventures, firms concede control over operating and financial decisions in return for opportunities to benefit from other firms' intangible and other assets. There are many business situations in which the moral hazard, monitoring, and other costs associated with joint ventures so reduce their values to potential participants that they outweigh the benefits of collaboration. International joint ventures are probably even more costly than their domestic counterparts, since information is less readily obtained at great distance, monitoring is more expensive, and the ability to coordinate operations and finances to minimize taxes is of particular value to owners of foreign investments. At the same time, international joint ventures may provide opportunities to explore markets and share risks and complementary technologies at relatively low cost.

${ }^{3}$ See, for example, Bond (1981), Slemrod (1990), Grubert and Mutti (1991), Hines and Rice (1994), and Hines (forthcoming). This literature is summarized recently by Hines (1996). 
Joint ventures have been extensively analyzed. The moral hazard problems that arise in cooperative efforts have attracted considerable attention since Holmstrom's (1982) finding that efficient sharing rules do not exist for certain types of partnerships. Subsequent work identifies circumstances in which efficient sharing rules may exist, including those with repeated play, unlimited liability, and those in which risk-averse agents use stochastic sharing rules." In the absence of complete contracts, joint ownership is generally suboptimal due to the sharing of residual control rights. $^{5}$ In the important case in which assets are jointly used, however, joint ownership may be an efficient arrangement. Aghion and Tirole (1994) find that "split" property rights can encourage innovation in settings with incomplete information. Similarly, the existence of potential spillovers means that parent firms may benefit from coordinated $R \& D$ activity in spite of the associated moral hazard problems. ${ }^{\circ}$ The moral hazard created by partnership arrangements can facilitate certain types of market transactions. Crampton et al. (1987) note that, in environments with incomplete information, joint ownership of an asset may be consistent with efficient resource allocation.

The theory of joint ventures carries implications for the structure of multinational business operations. Horstmann and Markusen (1995) suggest that two characteristics of economies, technological sophistication and growth of local markets, may influence the organizational form of efforts to explore new markets. They predict that faster market growth increases the benefits associated with information acquisition through joint ventures while greater technological sophistication reduces the likelihood of appropriation by a majority foreign partner. In contrast, Svejnar and Smith (1984) suggest that contracts between partners may make organizational forms

${ }^{4}$ See, for example, Legros and Matthews (1993).

'See, for example, Alchian and Demsetz (1972), Grossman and Hart (1986), Hart and Moore (1990), and Hart (1995).

'See Bhattacharya et al. (1992), Kamien et al. (1992), and Gandal and Schotchmer (1993) for examples. 
relatively unimportant from the standpoint of control. They note that joint venture partners can avoid moral hazard problems through prior agreements, and can arrange to receive profit shares in nondividend forms that need not be allocated in proportion to ownership shares.

Empirical studies identify three primary motivations for joint venture formation. The first is learning on the part of resource-constrained firms. Kogut (1991) characterizes joint ventures as "real options" that provide firms with information they can use in forming subsequent plans - that may include acquiring their partners or dissolving their joint ventures. Similarly, Balakrishnan and Koza (1993) view joint ventures as intermediate forms between markets and hierarchies that permit firms to overcome informational asymmetries at low cost. The second motivation is to placate host governments. Franko (1989), Gomes-Casseres (1990), and Contractor (1990) argue that sole ownership is generally preferred but occasionally conceded in bargains with host governments. The third, and most often cited, motivation is to economize on transaction costs. ${ }^{7}$ As outlined by Beamish and Banks (1987), Contractor and Lorange (1988) and Gomes-Casseres (1989), joint ventures balance the benefits of combining complementary assets with costs that include managerial conflicts and shirking. Hennart (1991) argues that the cost of using market transactions to purchase other firms' intermediate inputs makes joint ventures particularly attractive.

Surveys commonly report increasing use of joint ventures by multinational firms. Anderson (1990) and Geringer and Hebert (1991) claim that American firms rely to an ever-greater extent on international joint ventures, and will continue to do so. Curhan, Davidson, and Suri (1977) document a dramatic rise in the use of international joint ventures by American firms between 1951 and 1975 using survey data collected through the Harvard Multinational Project. Hladik (1985) extends Curhan et al.'s data through 1984 and projects continued growth of international joint ventures by U.S. firms.

These theories are reviewed in Caves (1996). 
Data

The available aggregate evidence on U.S. joint venture activity is reported by the Bureau of Economic Analysis of the U.S. Department of Commerce (BEA), which performs periodic benchmark surveys of the foreign operations of American multinational corporations. The two most recent surveys cover 1982 and 1989 . BEA $(1985,1992)$ reports data on country and industry bases including details on income statements, balance sheets, employment patterns, and parent-affiliate transactions such as royalty and interest payments. In addition, BEA (1985) tabulates responses to its 1982 survey of government-imposed ownership restrictions."

BEA reports aggregate figures for countries in which there is substantial U.S. investment; to protect the confidential ity of survey respondents, BEA suppresses information for countries in which one or two U.S. firms represent large fractions of total U.S. investment.9 The BEA data distinguish activities of majority-owned foreign affiliates of U.S. firms from activities of all affiliates owned at least $10 \%$ by U.S. firms. Differences between these two categorizations represent the activities of affiliates owned between $10 \%$ and $50 \%$ by U.S. firms. Throughout this paper we refer to such minority-owned affiliates as joint ventures. ${ }^{10}$

The 1982 BEA survey asks firms to indicate whether host governments limit the proportion of equity American parents can hold in their affiliates. BEA reports the fraction of respondents in each country indicating that they face such restrictions. This fraction can then be used as an index of the severity of local restrictions on foreign ownership shares, as in Contractor (1990).

These data supressions limit the available sample size for the statistical work presented in Tables 1-2 and 4-7. Countries in which joint venture activity falls to only one or two firms by 1989 are excluded from the sample, which reduces the chance of finding an effect of the U.S. tax change on joint venture activity. In addition, we follow Hines and Rice (1994) in excluding from our sample the major oil exporting countries in order not to confound the analysis with the special tax and regulatory issues that affect the oil industry. Adding data on oil exporting countries to the sample analyzed in the regressions reported in Tables 5-7 changes the results very little.

${ }^{10}$ American joint venture activity is concentrated in affiliates owned between $10 \%$ and $50 \%$ by American firms. Data reported by Mattaloni (1995) indicate that over $90 \%$ of the majority-owned foreign affiliates of U.S. firms are $100 \%$ owned. 
The tax treatment of multinational firms is discussed in detail in section 3.

Since U.S. firms pay corporate taxes to foreign host countries but on occasion receive special treatment in the form of tax holidays and other local tax concessions, it is necessary to calculate tax rates specifically applicable to American investors. Hines and Rice (1994) report such tax rates for 1982, and Appendix Table 2 lists comparable tax rates for 1989." In the statistical work, these tax rates are then truncated at $34 \%$ in order to reflect the tax costs of joint venture ownership by U.S. investors with excess foreign tax credits after 1986. National R\&D intensities are reported in National Science Foundation (1991); since relative magnitudes are very stable over time, ${ }^{12}$ only the 1988 cross-section is used. The Summers-Heston (1991) data base includes figures for real GDP; Mankiw et al. (1992) report long-term economic growth rates based on these data.

\section{Joint venture intensity in 1982}

Macroeconomic conditions appear to influence the formation of joint ventures. Table 1 presents information on U.S. joint venture intensity in different countries in 1982 . Joint venture intensity is the ratio of equity in minority-controlled U.S. foreign affiliates to equity in all U.S. foreign affiliates. ${ }^{13}$ Mean joint venture intensity among rapid GDP growth, high R\&D intensity countries is $31.8 \%$, which compares to $17.1 \%$ among slow growth, high R\&D intensity countries. Similarly, the mean joint venture intensity among high growth, low $R \& D$ intensity countries is

\footnotetext{
"Following Hines and Rice (1994), the tax rates listed in Appendix Table 2 equal the smaller of the statutory corporate tax rate for 1989 reported in Price Waterhouse (1989) and the average tax rate paid by American firms in 1989. The average tax rate is calculated as the ratio of income taxes paid by local affiliates of American firms to their local pre-tax income.

${ }^{12}$ See Hines (1995, pp. 235-236).

${ }^{13}$ There are other available measures of joint venture intensity, including those based on sales, assets, and property, plant and equipment. All yield similar results. Tables in the paper report results for equity intensities, since they are are less susceptible than other measures to data problems associated with the financing subsidiaries of nonfinancial corporations.
} 
$28.0 \%$, which compares to $4.4 \%$ among low-growth, low R\&D intensity countries. Joint ventures are concentrated in rapidly-growing and technologically advanced countries.

Table 2 presents results from OLS regressions in which the dependent variable is joint venture intensity in 1982. In the regressions reported in columns 1 and 2 the estimated effects of national GDP growth and R\&D intensity are positive but not significant. The interaction of GDP growth and R\&D intensity is positive and significant in the regression reported in column 3, while the estimated separate effects of GDP growth, R\&D intensity, and GDP level are insignificant. The regressions reported in columns 4 and 5 indicate that the 1982 tax rate has a positive and significant effect on joint venture intensity in 1982 , as do ownership restrictions imposed on foreign investors. The regression reported in column 5 implies that $10 \%$ greater ownership restrictions raise joint venture intensity by $11 \%$; that $10 \%$ higher taxes raise joint venture intensity by $5.3 \%$; and that a doubling of the mean interaction of GDP growth and R\&D intensity (from 0.05 to 0.1 ) would raise joint venture intensity by $21 \%$.

These results are consistent with theories of joint venture formation that emphasize the importance of market growth and technological sophistication. Ownership restrictions imposed by governments also have important effects. It is noteworthy that the patterns reported in Table 1 persist in subsamples distinguished by ownership restrictions. ${ }^{14}$

Joint venture intensities, 1982-1993

While the Benchmark surveys offer the most comprehensive information on the activities of U.S. multinationals, BEA provides more periodic data in annual supplements published

${ }^{14}$ Specifically, the pattern of joint venture intensity in the subsample of countries with few ownership restrictions in 1982 closely resembles that appearing in Table 1. 
since 1982 in the Survey of Current Business. ${ }^{15}$ Figure 1 uses these data to trace the joint venture intensities of U.S. affiliates in all foreign countries from 1982 through 1993, distinguishing affiliates in all industries from those in manufacturing. ${ }^{16}$ The time series is relatively stable between 1982 and 1986 , but features a significant break in 1987 or 1988 . Joint ventures constitute $22.8 \%$ of the assets of U.S.-owned foreign affiliates in 1982 , but only $18.8 \%$ by 1989 , which represents an $18 \%$ decline. Joint ventures constitute only $15.1 \%$ of the assets of U.S.-owned foreign affiliates in 1993.

Numbers of U.S.-owned international joint ventures, and numbers of U.S. parent firms with international joint ventures, show similar declines over the 1980 s. These numbers are available only in the Benchmark Surveys; Table 3 presents survey results for 1982 and 1989 . The top panel of Table 3 indicates that the number of international joint ventures by U.S. firms fell by $12.3 \%$ between 1982 and 1989, while the number of majority-owned ventures rose by $7.3 \%$. The bottom panel of Table 3 reports that the number of U.S. parent firms with international joint ventures fell by 11.4\% between 1982 and 1989 , while the number of U.S. parents with majority-owned affiliates rose by $6.9 \%$. The information presented in Figure 1 and Table 3 is consistent with the hypothesis that changes occurring around 1986 are responsible for a significant reduction in international joint venture activity by American firms.

\section{The 1986 Tax Change.}

In order to identify the impact of the 1986 TRA on U.S. joint ventures in foreign countries, it is helpful first to review the general features of U.S. taxation of foreign-source profits,

${ }^{15}$ Mataloni (1995) is an example.

${ }^{16}$ The figures presented in Figure 1 are ratios of joint venture assets to assets of all U.S. affiliates. Assets are used because BEA does not report equity figures on an annual basis. Alternative joint venture intensity measures calculated on the basis of employment or sales show patterns that are similar to that for assets depicted in Figure 1. 
second to consider the legislative history of TRA provisions that affect joint ventures, and third to analyze the incentives created by the Act.

\section{U.S. taxation of foreign-source profits ${ }^{17}$}

The United States taxes income on a "residence" basis, meaning that American corporations and individuals owe taxes to the U.S. government on all of their worldwide income, whether earned inside the United States or outside the United States. The top U.S. corporate tax rate was 34 percent in 1989 and is now 35 percent. Since foreign profits are usually taxed in host countries, U.S. law provides a foreign tax credit for income taxes (and related taxes) paid to foreign governments, thereby avoiding double taxation of American multinationals. Under U.S. law, an American corporation earning $\$ 100$ in a foreign country with a $10 \%$ tax rate (and a foreign tax obligation of $\$ 10$ ) pays only $\$ 25$ to the U.S. government, since its U.S. corporate tax liability of $\$ 35$ (35\% of $\$ 100$ ) is reduced to $\$ 25$ by the foreign tax credit of $\$ 10$. The foreign tax credit is, however, limited to U.S. tax liability on foreign income; if, in the example, the foreign tax rate were $\mathbf{5 0}$ percent, then the firm pays $\$ 50$ to the foreign government but its U.S. foreign tax credit is limited to \$35. Hence, an American firm receives full credits for its foreign taxes paid only when it is in a "deficit credit" position, i.e., when its average foreign tax rate is less than its tax rate on domestic operations. A firm has "excess credits" if its available foreign tax credits exceed U.S. tax tax liability on its foreign income. ${ }^{18}$

Deferral of U.S. taxation of certain foreign earnings is another important feature of the U.S. international tax system. An American firm is taxed on a subsidiary's foreign income only

\footnotetext{
${ }^{17}$ Portions of this brief description of U.S. tax law are excerpted from Hines (1991).

${ }^{17}$ In order to receive foreign tax credits for foreign taxes paid by affiliates, U.S. firms must have at least $10 \%$ ownership shares. A further restriction is that only those taxes that qualify as income taxes are creditable.
} 
when repatriated to the parent corporation; this type of deferral is available only to foreign affiliates that are separately incorporated as subsidiaries in foreign countries. The ability to defer homecountry taxes may create incentives to delay repatriating dividends from foreign subsidiaries. ${ }^{19}$ This incentive arises in those cases in which firms expect never to repatriate their foreign earnings, or those in which they anticipate that future years will be more attractive for repatriation (either because domestic tax rates will be lower or because future sources of foreign income will generate excess foreign tax credits that can be used to offset U.S. tax liability on the dividends).

Firms are required to construct averages of their taxable incomes and taxes paid in all foreign operations when calculating foreign tax credits and foreign tax credit limits. This system of worldwide averaging was put in place in 1976. As a consequence of worldwide averaging, American investors in low-tax locations such as Hong Kong can avoid U.S. tax otherwise due upon repatriation of dividends if the firm has sufficient income from high-tax foreign locations such as Germany with which the Hong Kong income and taxes can be averaged.

U.S. law limits worldwide averaging by requiring firms to calculate foreign tax credits separately for different sources of income, known as "baskets." An example is income from petroleum extraction, which is usually very heavily taxed by host countries, and with which Congress is unwilling to let firms average their other foreign income in calculating foreign tax credits.

Consequently, petroeum income has its own "basket" and it is therefore possible for some companies to have excess foreign tax credits in the "petroleum basket" while having deficit foreign tax credits in the "active basket" (consisting of active foreign-source income).

${ }^{19}$ The incentive to delay repatriation of lightly taxed foreign earnings is greatly reduced by the Subpart F rules enacted by Congress in 1962. These rules apply to controlled foreign corporations, which are foreign corporations owned at least $50 \%$ by American firms or individuals holding stakes of at least $10 \%$ each. Under Subpart F, a subsidiary's passive income, and any income invested in U.S. property, are treated as if distributed to its American owners, thereby subjecting that income to immediate U.S. taxation. Controlled foreign corporations that reinvest their foreign earnings in active businesses can continue to defer their U.S. tax liability on those earnings. 
The Tax Reform Act of 1986

The Tax Reform Act of 1986 greatly increased the number of "baskets" used by American firms to calculate foreign tax credit limits. In particular, the TRA segregates income from joint ventures owned 50\% or less by Americans into distinct "baskets" - separate "baskets" for each venture - thereby preventing worldwide averaging of foreign tax credits. ${ }^{20}$ While it is possible to avoid the separate "basket" treatment of joint ventures, the steps that must be taken to do so are sufficiently costly that they are used only on occasion. ${ }^{21}$

The history of the TRA offers some clues to Congress's thought process in enacting such a change. President Reagan (1985, pp. 385-396) originally proposed that the United States eliminate altogether the use of worldwide averaging in calculating foreign tax credit limits, arguing that worldwide averaging can give U.S. firms excessive incentives to invest in low-tax foreign countries and also encourages some high-tax foreign countries to maintain their high tax rates. Congress was unwilling to adopt the President's plan, feeling that, for a given total income accruing to a multinational firm, the distribution of that income between affiliates located in different foreign

\footnotetext{
${ }^{20}$ Other "baskets" introduced by the TRA include those for passive income, high withholding tax interest, financial services income, and shipping income.

${ }^{21}$ Tillinghast (1990), Crawford and Hoke (1995), and Skaletsky and Shackelford (1996) discuss some of the methods used to avoid separate "basket" treatment of income from joint ventures. These methods involve either diluting the foreign partner's ownership through the purchase of stock or additional options in the joint venture, or else reorganizing the ownership of the joint venture by setting up a separate entity to own the U.S. share in the foreign joint venture. The first alternative is costly from the standpoint of relations with foreign partners, while the second triggers additional U.S. taxes through Subpart F, leading Tillinghast $(1990$, p. 224) to conclude that "in many cases ... these techniques do not work." A third alternative is to establish a foreign joint venture as a partnership rather than a separate corporation. Such an arrangement entails various legal and business costs and prevents American owners from deferring U.S. taxation of foreign income. There exist hybrid structures that are partnerships from the standpoint of U.S. law and corporations from the standpoint of foreign law, from which income is not subject to separate "basket" treatment. But deferral of U.S. taxation is not permitted with such structures, and U.S. regulations are such that McClellan, Rieu and Conlon (1996, p. 2) find that "Achieving hybrid treatment using these rules is often complex, expensive, and time consuming and can result in a structure that is commercially limited."
} 
countries has little economic significance. Since country-by-country foreign tax credit limits also impose greater administrative burdens on firms and tax authorities, Congress preferred to continue treating the foreign activities of U.S. multinational firms as integrated units for U.S. tax purposes.

Congress was reluctant, however, to apply the same logic to joint ventures in which Americans hold ownership stakes of $50 \%$ or less, believing that such entities have insufficient "identity of interest with U.S. shareholders to treat nonmajority ownership positions as units of a worldwide busines. " 2 In addition, Congress was anxious to deter the use of minority American ownership as a tax avoidance strategy in low-tax countries. ${ }^{20}$ Consequently, the TRA removes worldwide averaging of foreign tax credits for such ventures. Since the TRA retains worldwide averaging of foreign tax credits for majority-owned U.S. affiliates, the tax change strongly encourages substitution of one organizational form for another.

The Tax Reform Act of 1986 introduced other important changes, notably reducing the statutory U.S. corporate tax rate from $46 \%$ to $34 \%$. This rate reduction increased the number of U.S. multinationals with excess foreign tax credits. ${ }^{24}$ The data presented below suggest that the

${ }^{2}$ Congressional sentiment is described in U.S. Congress (1987, pp. 867-868). Congress's reasoning has been questioned by Tillinghast (1990), who argues that, since U.S. law deems $10 \%$ ownership to be sufficient for firms to claim foreign tax credits, it should also suffice to treat an affiliate as part of a worldwide group.

${ }^{2}$ Since minority joint ventures are not Controlled Foreign Corporations, they are not subject to the Subpart F rules, and American owners can defer U.S. taxation of their unrepatriated passive foreign income. One function of the joint venture provisions of the TRA was to prevent the expanded use of tax haven investment funds with minority U.S. ownership and low payout rates. Crawford and Hoke (1995, p. 1767) note that the TRA was successful in this regard, since the post-1986 separate basket treatment of joint ventures is typically more costly than loss of deferral occasioned by the Subpart $F$ rules.

${ }^{24} \mathrm{Grubert}$, Randolph and Rousslang (1996) report that firms with excess foreign tax credits received 33\% of the foreign income of U.S. corporations in 1984, and 66\% in 1990 . They note that even this $66 \%$ figure is smaller than the $79 \%$ predicted right after passage of the TRA, and conjecture that contemporaneous foreign tax law changes along with endogenous behavior of American companies may account for the difference. They also note that the fraction of income received by firms with excess foreign tax credits appears to be falling over time, reaching 35\% in 1992. 
confluence of these changes discourages the use of joint ventures in low tax countries as such investments became considerably more costly.

\section{Incentives created by the TRA}

It is helpful to specify an American multinational's valuation of its foreign affiliates in order to distinguish some of the possible reactions to tax changes. We consider operations with locally decreasing returns to scale production functions, but for simplicity, analyze the valuation of an affiliate with fixed total capitalization (normalized to equal unity). We analyze three characteristics: (i) the fraction of debt in the capital structure, denoted $\delta$; (ii) the U.S. share of equity ownership, denoted $s$ (with $0<s \leq 0.5$ for joint ventures); and (iii) the extent of technology transfer from the American parent firm to the joint venture, denoted $T$. Naturally, the foreign affiliate makes numerous other decisions that influence its profitability, but these are suppressed in order to focus on the three variables of interest. The American parent firm is assumed to have excess foreign tax credits after 1986.

Denote by $\mathrm{Q}^{i}(\mathrm{~s}, \delta, \mathrm{T})$ the one-period output generated by a unit investment in a joint venture located in country $i$. Not all of this output is available for distribution to the owners of the affiliate, however, since royalties, interest, and taxes must be paid first. Let $\rho(T)$ denote the royalty that is paid to the American investor as compensation for providing $T$ units of technology to the affiliate. The one-period market interest rate is given by $r$, so the one-period cost of debt is $r \delta$. The affiliate's before-tax income is: $\left[Q^{i}(s, \delta, T)-\rho(T)-r \delta\right]$, and its income after foreign taxes is:

$$
\left[Q^{i}(s, \delta, T)-\rho(T)-r \delta\right]\left(1-\tau^{*}\right)
$$

We consider steady states in which affiliates pay dividends equal to after-tax profits, 
thereby maintaining their debt/equity ratios at $\delta$ and their capitalizations at unity. An American partner receives the following value (V) from its participation in the joint venture:

$$
\mathrm{V}=\mathrm{s}\left[\mathrm{Q}^{\mathrm{i}}(\mathrm{s}, \delta, \mathrm{T})-\rho(\mathrm{T})-\mathrm{r} \delta\right]\left(1-\tau^{*}\right)\left(1-\tau_{\mathrm{US}}\right)+\rho(\mathrm{T})-\mathrm{c}^{\mathrm{i}}(\mathrm{s}, \mathrm{T})-\lambda s(1-\delta)
$$

in which $\tau_{\text {us }}$ represents the effective U.S. tax rate on dividends received from joint ventures in country $i$, and $c^{i}(s, T)$ is the spillover cost associated with transferring technology $T$ to a joint venture located in country $i$ in which the U.S. parent owns share s. The last term, $\lambda s(1-\delta)$, reflects the cost of investing equity capital in the joint venture; $\lambda$ is the one-period cost of equity funds, while $s(1-\delta)$ is the investment necessary to obtain a share s of the affiliate's equity.

American firms cannot generally select $s, \delta$, and $T$ to maximize the value of their participation in joint ventures, since foreign partners typically have differing objectives or opinions about the appropriate division of ownership shares, debt/equity ratios, and use of proprietary American technology. Furthermore, some host governments restrict foreign ownership of local enterprises.

It is useful to consider the effect of changes in $r_{\text {us }}$ on the value of U.S. participation in joint ventures. Higher rates of $\tau_{\text {us }}$ reduce after-tax returns available to American investors, thereby reducing the attractiveness of joint venture activity. As a consequence, Americans are likely to reduce the number of joint ventures in which they participate. The cost of a higher rate of $\tau_{\text {us }}$ is not the same for all affiliates, since affiliates with higher debt ratios or greater royalty payments escape some of the effect of higher U.S. taxation. ${ }^{25}$ One expects, therefore, that in low-tax countries in which dividends received from joint ventures become more expensive after 1986 , American firms will participate in fewer joint ventures. The joint ventures in which they do

\footnotetext{
${ }^{25}$ It is easily verified that $\partial^{2} \mathrm{~V} / \partial \tau_{\mathrm{US}}^{i} \partial \rho>0$, as is $\partial^{2} \mathrm{~V} / \partial \tau_{\mathrm{US}} \partial \delta$.
} 
participate after 1986 should be heavily leveraged, and if possible structured to compensate American investors with royalties instead of dividends. ${ }^{20}$ Alternatively, if firms choose organizational form entirely on commercial or strategic grounds and without regard to tax costs, there should be no taxrelated changes in the relative joint venture intensities of U.S. operations in low tax and high tax countries after 1986. Consequently, post-1986 patterns of joint venture activity permit measurement of the elasticity of organizational form to tax costs.

\section{Responses to the 1986 tax change.}

The changes introduced by the 1986 TRA raise the tax costs of joint ventures, particularly those in low-tax countries. The impact of the TRA is a function of capital structure and propensity to pay royalties to American owners. This section investigates whether the pattern of joint venture activity after 1986 is consistent with substitution in response to these incentives.

\section{Changes in investment patterns}

The data described in the top panel of Table 4 indicate that U.S. joint venture activity in low tax countries grew more slowly between 1982 and 1989 than did majority owned U.S. business activity, while the reverse is true in high tax countries. Equity in U.S.-owned joint ventures in low tax countries had mean growth of $53.8 \%$, while equity in majority owned U.S. affiliates in the same countries grew by $129.2 \%$. American joint ventures in high-tax countries between 1982 and 1989 grew by $220.2 \%$, while the corresponding figure for U.S. majority owned affiliates is $53.2 \%$. These

\footnotetext{
${ }^{20}$ Not all of these implications are guaranteed by the comparative statics derived from (2). For example, it is possible that $\partial^{2} c^{i}(\mathrm{~s}, \mathrm{~T}) / \partial \mathrm{s} \partial \mathrm{T}<0$ (as noted by Nakamura and Yeung, 1994), since foreign partners with greater ownership shares may be in good positions to obtain proprietary technologies transferred to joint ventures. If this is an important consideration, then higher values of $\tau_{\text {us }}$ that significantly reduce $s$ may thereby reduce $T$ and $\rho$ in spite of the incentive to substitute royalties for dividends.
} 
growth rates suggest that whatever is responsible for the relative stagnancy of U.S. joint venture activity in low-tax countries did not affect joint ventures in high-tax countries. The pattern evident in Table 4 persists in subsamples distinguished by equity restrictions: U.S. joint ventures grew relatively more slowly in low tax countries with few ownership restrictions than they did in high tax countries with few ownership restrictions.

Table 5 presents OLS estimates of the impact of foreign tax rates on growth rates of equity in U.S. joint ventures and majority-owned U.S. affiliates between 1982 and 1989. Columns 1 and 2 present regression results for growth rates of joint ventures. The estimated effect of taxation is positive and significant in the regression reported in column 1 , indicating that $1 \%$ lower foreign tax rates are associated with $6.9 \%$ slower growth of joint ventures over the seven years between 1982 and 1989. Since the mean tax rate in the sample is $25.0 \%$ and the mean growth rate of joint ventures is $140.8 \%$, this corresponds to a -1.23 elasticity of joint venture growth with respect to tax costs. The regression in column 2 adds as an explanatory variable ownership restrictions in 1982, thereby capturing the effect of gradual ownership liberalizations during the $1980 \mathrm{~s}^{27}$ The estimated tax coefficient remains positive and significant, and is somewhat larger than that reported in column 1, while the effect of ownership restrictions is negative (as expected) and insignificant.

Columns 3 and 4 of Table 4 report coefficient estimates from regressions with the growth of majority-owned U.S. affiliates as the dependent variable. The estimated tax effect is negative and insignificant in both regressions, as is the effect of ownership restrictions in the

\footnotetext{
${ }^{27}$ The reason to include ownership restrictions as an explanatory variable is to avoid omitted variable bias that could arise if tax rates are correlated with changes in ownership restrictions during the sample period. Unfortunately, BEA did not ask U.S. firms about local ownership restrictions in its 1989 survey, so it is not possible to construct a variable equal to the difference between the fraction of U.S. firms required to limit their ownership of local affiliates in 1989 and the same fraction in 1982. Since ownership restrictions were generally liberalized in the 1980s, the 1982 fraction is a proxy for changes over the decade. An alternative method of controlling for changes in ownership restrictions is to limit the sample to countries with very few restrictions in 1982. The regressions reported in Tables 5-7 were re-run on this subsample, with results that are similar to those obtained with the larger sample.
} 
regression reported in column 4 . These results suggest that the positive effect of tax rates on joint venture growth does not reflect omitted variables that influence business activity generally, since the same effect does not appear in estimates of growth of majority owned affiliates. The regressions reported in columns 5 and 6 make such a comparison more explicit: the dependent variable in these regressions is the difference between joint venture growth and the growth of majority owned affiliates. The results indicate that foreign tax rates have positive and significant effects on this difference. The point estimate of the tax coefficient reported in column 6 indicates that $1 \%$ lower foreign tax rates are associated with $10.7 \%$ slower growth of joint ventures, relative to majority owned affiliates, between 1982 and 1989. Alternative specifications of these regressions produce similar results. ${ }^{28}$

The tax rate variable used in the regressions reported in Table 5 is potentially endogenous to changes in the form of U.S. investment, as it is based on average tax rates that may differ between joint ventures and majority owned affiliates. In order to explore the sensitivity of the results to this consideration, the regressions reported in Tables 5-7 were re-run using 1982 tax rates in place of 1989 tax rates. The results, which are reported in Appendix Tables 3-5, differ little from those obtained using 1989 tax rates. ${ }^{29}$

\footnotetext{
${ }^{28}$ Regressions in which the dependent variable is redefined as the fraction of assets or property plant and equipment (instead of equity) held by U.S. joint ventures produce results that are similar to those reported in Table 5. Since not all U.S. multinational firms have excess foreign tax credits in 1989, it is useful to consider an alternative specification of the tax rate variable that captures the cost of separate "basket" treatment of joint ventures in high tax countries owned by parents with deficit foreign tax credits that are thereby unable to cross-credit tax payments made by their joint ventures. The alternative definition of the tax variable is the absolute value of the difference between 0.34 and the local tax rate. Regressions using this tax variable produce results that are consistent with those reported in Tables 5-7.

${ }^{29}$ Alternative IV specifications in which 1982 tax rates are used as instruments for 1989 tax rates also generate results that are similar to those reported in Tables 5-7.
} 


\section{Changes in royalty payment patterns}

The middle panel of Table 4 describes changes in royalties between 1982 and 1989 for joint ventures and majority owned affiliates. Royalties are defined as the ratio of royalties paid to U.S. parents to total affiliate equity. Mean royalty payments by U.S.-owned joint ventures in low tax countries declined by $0.03 \%$, while royalty payments by joint ventures in high tax countries declined by $0.31 \%$. The opposite pattern appears in royalty payments by majority owned U.S. affiliates: mean royalties rose by $0.35 \%$ in low tax countries and by $1.12 \%$ in high tax countries. These differences are consistent with U.S. owners' incentives to transfer technology rather than capital after 1986 to their joint ventures in countries with low tax rates, thereby substituting royalties for dividends.

Table 6 presents estimates of the impact of foreign tax rates on changes between 1982 and 1989 in ratios of royalty payments to affiliate equity. ${ }^{30}$ Columns 1 and 2 present regression results for royalty payments by joint ventures, in which foreign tax rates have negative and significant effects on royalties. Foreign tax rates have positive and significant effects on royalty payments by majority owned affiliates in the regressions reported in columns 3 and 4 . The dependent variable in the regressions reported in columns 5 and 6 is the difference between the change in royalties paid to U.S. owners by joint ventures and the change in royalties paid by majority owned affiliates. The results indicate that foreign tax rates significantly influence this difference. The point estimate of the tax coefficient reported in column 6 indicates that $1 \%$ lower foreign tax rates are associated with $0.052 \%$ higher royalty payments by joint ventures than by majority owned affiliates. Since government regulations require royalty payments to correspond to technology transfers, these results imply that U.S. firms respond to higher tax costs of dividends by investing technology rather than

\footnotetext{
${ }^{30}$ Similar results appear when the dependent variable is redefined as the ratio of royalty payments to affiliate assets. Results are also similar when royalty payments in both 1982 and 1989 are normalized by 1982 equity.
} 
capital in their affiliates. ${ }^{31}$

\section{Changes in capital structure}

In raising the tax cost of dividends received from joint ventures in low tax countries, the 1986 TRA encourages affiliates to substitute borrowing for equity. While a number of studies investigate the influence of the TRA on borrowing patterns, ${ }^{32}$ there is little examination of its impact on affiliates of different organizational types. The bottom panel of Table 4 describes changes in leverage ratios between 1982 and 1989 for joint ventures and majority owned affiliates. Leverage ratios are ratios of debt to total assets. ${ }^{33}$ The mean leverage ratios of U.S.-owned joint ventures in low tax countries rose by $7.4 \%$ between 1982 and 1989 , while leverage ratios of joint ventures in low tax countries fell by $3.0 \%$. Leverage ratios of majority owned U.S. affiliates show the opposite pattern with far less variability: the mean leverage ratio in low tax countries fell by $2.2 \%$, while leverage ratios in high tax countries fell by $1.1 \%$. This pattern is consistent with incentives introduced in 1986 to economize on dividend payments from joint ventures in countries with low tax rates.

Table 7 presents estimates of the effect of foreign tax rates on changes in leverage ratios between 1982 and 1989. Column 1 presents regression results for leverage ratios of joint ventures, in which foreign tax rates have negative but insignificant effects on leverage. The results

\footnotetext{
${ }^{31}$ Another possibility is that firms substitute royalty payments for dividends in response to the tax incentives without changing the amount of transferred technology. Kopits (1976), Hines (1995) and Grubert (1995) estimate the responsiveness of royalty payments to tax incentives. Since technology transfers are unobservable, it is not possible to distinguish completely technology substitution from adept accounting with the available data.
}

${ }^{32}$ See Collins and Shackelford (1992), Altshuler and Mintz (1995), and Froot and Hines (1995).

${ }^{33}$ The numerator of the leverage ratio is long-term debt plus current liabilities other than trade accounts and payables. 
reported in column 2 indicate that foreign tax rates have positive and insignificant effects on the leverage ratios of majority owned affiliates. The dependent variable in the regression reported in column 3 is the difference between the changes in the leverage ratios of joint ventures and majority owned affiliates. The results indicate that foreign tax rates have a negative and significant effect on this difference, the point estimate implying that $1 \%$ lower foreign tax rates are associated with $0.81 \%$ higher ratios of debt to assets in joint ventures than in majority owned affiliates.

The ability of U.S. partners to effect such changes in capital structure and technology transfer without control is notable. While the capital structure changes documented in Table 7 might have been determined by the foreign majority owners without input from U.S. partners, the difference in leverage ratio changes between joint venture affiliates in low and high tax countries raises the possibility that U.S. partners exert control over capital structure choices in joint venture affiliates.

\section{Conclusion.}

The evidence indicates that U.S. multinationals significantly altered their joint venture activity in response to the incentives created by the Tax Reform Act of 1986 . This response appears in patterns of investment, capital structure, and technology transfer as reflected by royalty payments. This behavior is consistent both with withdrawal from overseas joint ventures and with substitution of majority (or 100\%) ownership for joint venture participation. While it is difficult to distinguish these reactions on the basis of available data, it is clear that Congress's effort to create separate "baskets" for foreign joint ventures succeeded in significantly reducing American joint venture activity after 1986.

Previous theoretical and empirical work emphasizes the role of joint ventures in exploring new markets and in high technology industries. To the extent that joint ventures provide unique opportunities, the separate "basket" provisions of the TRA significantly weaken the 
competitive positions of U.S. firms in foreign markets. Such an outcome certainly was not President Reagan's intention in first proposing tax reform in 1985 and probably was not Congress's in passing the TRA.

The organization of international business appears to be very sensitive to its tax treatment. In their survey of U.S. taxation of international income, Ault and Bradford (1990) point to the centrality of control distinctions in the classification of income, and note the links between control, tax rules, and the notion of "competitiveness." The changed U.S. tax environment after 1986 made it more difficult for foreign firms, particularly those in low tax countries, to attract and keep U.S. partners. In response, successful joint ventures became more heavily leveraged and made greater use of royalties to compensate U.S. investors. These reactions suggest that traditional definitions of control - as ownership stakes greater than $51 \%$ - may not fully describe the relationship between joint owners. 
Aghion, Philippe and Jean Tirole, 1994, "The management of innovation, " Quarterly Journal of Economics, 109, 1185-1209.

Alchian, Armen A. and Harold Demsetz, 1972, "Production, information costs, and economic organization," American Economic Review, 62, 777-795.

Altshuler, Rosanne and Jack M. Mintz, 1995, "U.S. interest-allocation rules: Effects and policy," International Tax and Public Finance, 2, 7-35.

Anderson, Erin, 1990, “Two firms, one frontier: On assessing joint venture performance,” Sloan Management Review, 31, 19-30.

Ault, Hugh J. and David F. Bradford, 1990, "Taxing international income: An analysis of the U.S. system and its economic premises," in Assaf Razin and Joel Slemrod, eds. Taxation in the global economy (Chicago: University of Chicago Press).

Balakrishnan, Srinivasan and Mitchell P. Koza, 1993, "Information asymmetry, adverse selection, and joint ventures," Journal of Economic Behavior and Organization, 20, 99-117.

Beamish, Paul W. and John C. Banks, 1987, "Equity joint ventures and the theory of the multinational enterprise," Journal of International Business Studies, 18, 1-16.

Bhattacharya, Sudipto, Jacob Glazer, and David E. M. Sappington, 1992, "Licensing and the sharing of knowledge in research joint ventures," Journal of Economic Theory, 56, 43-69.

Bleeke, Joel and David Ernst, 1993, "Postscript," in Joel Bleeke and David Ernst, eds. Collaborating to compete: Using strategic alliances and acquisitions in the global marketplace (New York: Wiley).

Bond, Eric, 1981, "Tax holidays and industry behavior," Review of Economics and Statistics, 63, 88-95.

Caves, Richard E., 1996, Multinational enterprise and economic analysis, 2nd ed. (Cambridge, UK: Cambridge University Press).

Collins, Julie H. and Douglas A. Shackelford, 1992, "Foreign tax credit limitations and preferred stock issuances," Journal of Accounting Research Supplement, 30, 103-124.

Contractor, Farok J., 1990, "Ownership patterns of U.S. joint ventures abroad the the liberalization of foreign government regulations in the 1980s: Evidence from the benchmark surveys," Journal of International Business Studies, 21, 55-73.

Crampton, Peter, Robert Gibbons, and Paul Klemperer, 1987, "Dissolving a partnership efficiently," Econometrica, 55, 615-632. 
Crawford, Russell W. and William D. Hoke, 1995, "Nonmonetary capitalizations and strategic alliances - using existing property," Tax Notes International, 11, December 25, 1757-1771.

Curhan, Joan P., William H. Davidson, and Rajan Suri, 1977, Tracing the multinationals (Cambridge, MA: Ballinger).

Franko, Lawrence G., 1989, "Use of minority and 50-50 joint ventures by United States multinationals during the 1970s: The interaction of host country policies and corporate strategies," Journal of International Business Studies, 20, 19-40.

Froot, Kenneth A. and James R. Hines Jr., 1995, "Interest allocation rules, financing patterns, and the operations of U.S. multinationals," in Martin Feldstein, James R. Hines Jr., and R. Glenn Hubbard, eds. The effects of taxation on multinational corporations (Chicago: University of Chicago Press).

Gandal, Neil and Suzanne Scotchmer, 1993, "Coordinating research through research joint ventures," Journal of Public Economics, 51, 173-194.

Gentry, William M., 1994, "Taxes, financial decisions and organizational form: Evidence from Publicly Traded Partnerships," Journal of Public Economics, 53, 223-244.

Geringer, J. Michael and Louis Hebert, "Measuring performance of international joint ventures," Journal of International Business Studies, 22, 249-263.

Gomes-Casseres, Benjamin, 1989, "Ownership structures of foreign subsidiaries: Theory and evidence," Journal of Economic Behavior and Organization, 11, 1-25.

Gomes-Casseres, Benjamin, 1990, "Firm ownership preferences and host government restrictions: An integrated approach," Journal of International Business Studies, 21, 1-22.

Gordon, Roger H. and Jeffrey K. MacKie-Mason, 1990, "Effects of the Tax Reform Act of 1986 on corporate financial policy and organizational form," in Joel Slemrod, ed. Do taxes matter? The impact of the Tax Reform Act of 1986 (Cambridge, MA: MIT Press).

Gordon, Roger H. and Jeffrey K. MacKie-Mason, 1994, "Tax distortions to the choice of organizational form," Journal of Public Economics, 55, 279-306.

Grossman, Sanford J. and Oliver D. Hart, 1986, "The costs and benefits of ownership: A theory of vertical and lateral integration," Journal of Political Economy, 94, 691-719.

Grubert, Harry, 1995, "Royalties, dividends, and R\&D," in Proceedings of the eighty-seventh annual conference on taxation (Columbus, $\mathrm{OH}$ : National Tax Association).

Grubert, Harry and John Mutti, 1991, "Taxes, tariffs and transfer pricing in multinational corporation decision making," Review of Economics and Statistics, 73, 285-293. 
Grubert, Harry, William C. Randolph, and Donald J. Rousslang, 1996, "Country and multinational company responses to the Tax Reform Act of 1986," mimeograph, Office of Tax Analysis, United States Department of the Treasury.

Hart, Oliver, 1995, Firms, contracts, and financial structure (Oxford: Oxford University Press).

Hart, Oliver and John Moore, 1990 "Property rights and the nature of the firm," Journal of Political Economy, 98, 1119-58.

Hennart, Jean-François, 1991, "The transaction costs theory of joint ventures: An empirical study of Japanese subsidiaries in the United States," Management Science, 37, 483-497.

Hines, James R., Jr., 1991, "The flight paths of migratory corporations, " Journal of Accounting, Auditing, and Finance, 6, 447-479.

Hines, James R., Jr., 1995, "Taxes, technology transfer, and the R\&D activities of multinational firms," in Martin Feldstein, James R. Hines Jr., and R. Glenn Hubbard, eds. The effects of taxation on multinational corporations (Chicago: University of Chicago Press), 225-248.

Hines, James R., Jr., 1996, "Tax policy and the activities of multinational corporations," NBER Working Paper No. 5589.

Hines, James R., Jr., forthcoming, "Altered states: Taxes and the location of foreign direct investment in America," American Economic Review.

Hines, James R., Jr. and Eric M. Rice, 1994, "Fiscal paradise: Foreign tax havens and American business," Quarterly Journal of Economics, 109, 149-182.

Hladik, Karen J., 1985, International joint ventures: An economic analysis of U.S. foreign business partnerships (Lexington, MA: Lexington Books).

Holmstrom, Bengt, 1982, “Moral hazard in teams," Bell Journal of Economics, 13, 324-340.

Horstmann, lgnatius J. and James R. Markusen, 1995, "Exploring new markets: Direct investment, contractual relations and the multinational enterprise," NBER Working Paper No. 5029.

Kamien, Morton I., Eitan Muller, and Israel Zang, 1992, "Research joint ventures and R\&D cartels," American Economic Review, 82, 1293-1306.

Kogut, Bruce, 1991, "Joint ventures and the option to expand and acquire," Management Science, 37, 19-33.

Kopits, George F., 1976, "Intra-firm royalties crossing frontiers and transfer-pricing behavior," Economic Journal, 86, 791-805.

Legros, Patrick and Steven A. Matthews, 1993, "Efficient and nearly efficient partnerships," Review of Economic Studies, 68, 599-611. 
Mankiw, N. Gregory, David Romer, and David Weil, 1992, "A contribution to the empirics of economic growth," Quarterly Journal of Economics, 107, 407-437.

Mattaloni, Raymond J., Jr., 1995, “U.S. multinational companies: Operations in 1993," Survey of Current Business, June, 75, 31-51.

McClellan, Arnold, Ed Rieu, and Roger Conlon, 1996, "'Check the box' - proposed US entity classification rules open tax-planning opportunities," World Tax News (New York: Deloitte Touche Tohmatsu International), July, 7, 1-3.

Nakamura, Masao and Bernard Yeung, 1994, "On the determinants of foreign ownership shares: Evidence from US firms' joint ventures in Japan," Managerial and Decision Economics, 15, 95-106.

National Science Foundation, 1991, International science and technology data update: 1991, NSF 91-309, (Washington, D.C.: National Science Foundation).

President of the United States, 1985, The President's tax proposals to the Congress for fairness, growth, and simplicity (Washington, D.C.: Government Printing Office).

Price Waterhouse, 1989, Corporate taxes: A worddwide summary (New York: Price Waterhouse).

Skaletsky, Marc S. and Douglas A. Shackelford, 1996, "U.S. tax deferral considerations and strategies," Tax Notes International, 12, January 8, 125-153.

Slemrod, Joel, 1990, "Tax effects on foreign direct investment in the United States: Evidence from a cross-country comparison," in Assaf Razin and Joel Slemrod, eds. Taxation in the global economy (Chicago: University of Chicago Press).

Summers, Robert and Alan Heston, 1991, "The Penn World Table (Mark 5): An expanded set of international comparisons," Quarterty Journal of Economics, 106, 327-368.

Svejnar, Jan and Stephen C. Smith, 1984, "The economics of joint ventures in less developed countries," Quarterty Journal of Economics, 99, 149-167.

Tillinghast, David R., 1990, "International tax simplification," American Journal of Tax Policy, 8, 187-247.

U.S. Congress, Joint Committee on Taxation, 1987, General explanation of the Tax Reform Act of 1986 (Washington, D.C.: Government Printing Office).

U.S. Department of Commerce, Bureau of Economic Analysis, 1985, U.S. direct investment abroad: 1982 benchmark survey data (Washington, D.C.: Government Printing Office).

U.S. Department of Commerce, Bureau of Economic Analysis, 1992, U.S. direct investment abroad: 1989 benchmark survey data, final results (Washington, D.C.: Government Printing Office). 
Figure 1

Joint Venture Share of Foreign Affiliate Assets, 1982-1993

$30.00 \%$

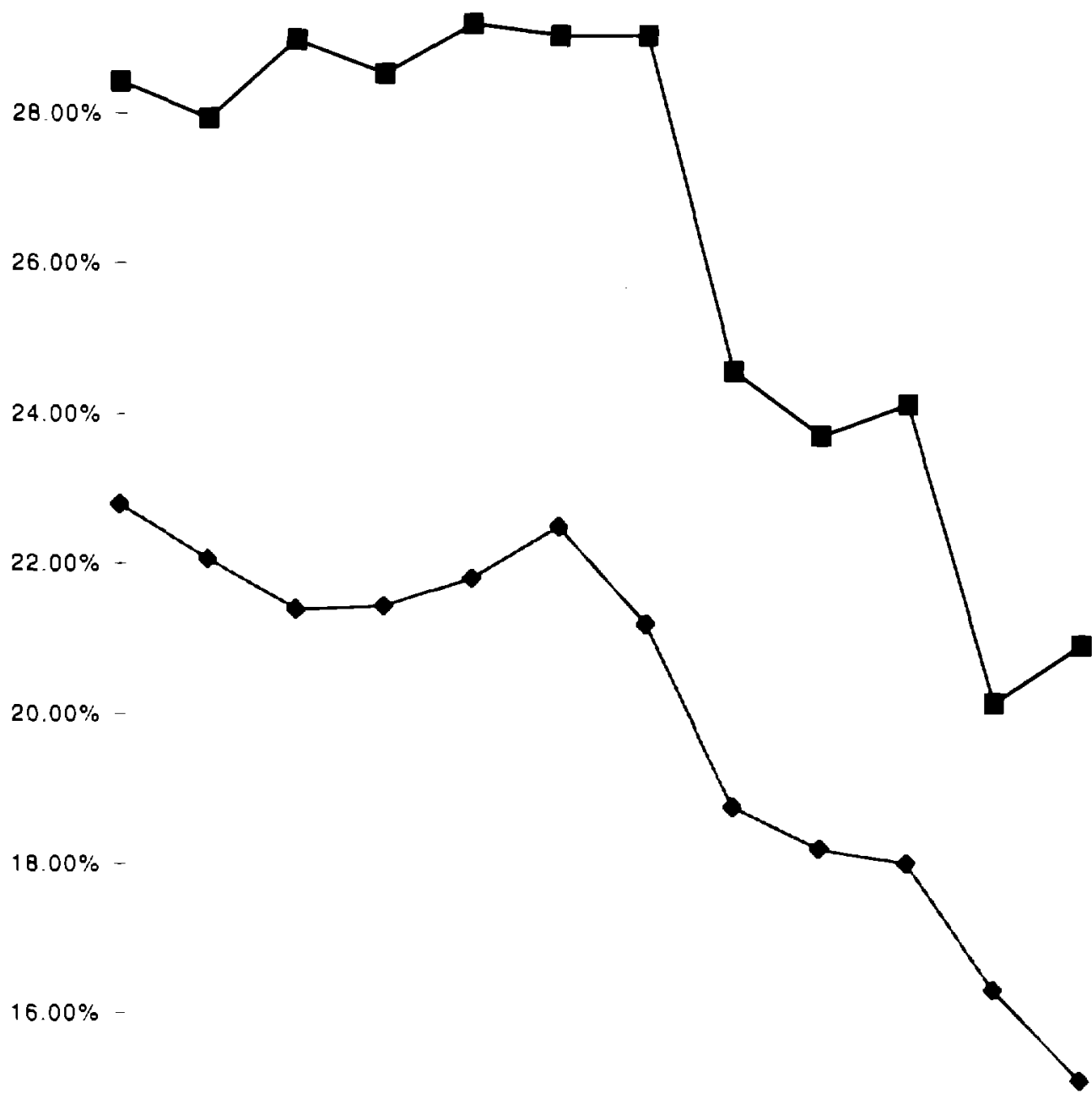

$14.00 \%$

$12.00 \%-$

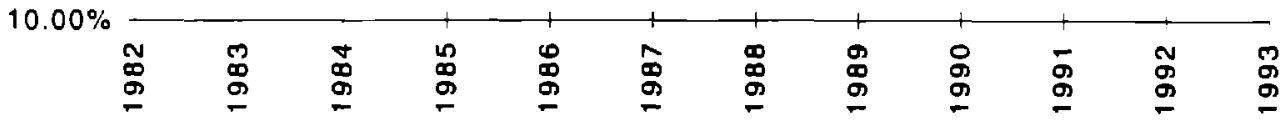

Source: U.S. Department of Commerce, Bureau of Economic Analysis 
Table 1

U.S. Joint Venture Intensity, by GDP Growth and R\&D Intensity, 1982

Fraction of Total Affiliate Equity in Joint Venture Form

\begin{tabular}{llcc}
\hline & & Fast GDP Growth & Slow GDP Growth \\
\cline { 3 - 4 } High R\&D Intensity & Mean & 0.3182 & 0.1711 \\
& Median & 0.2116 & 0.1350 \\
& Std. dev. & 0.2805 & 0.1287 \\
\# of Countries & & 8 & 15 \\
Low R\&D Intensity & Mean & 0.2795 & 0.0437 \\
& Median & 0.2887 & 0.0367 \\
\# of Countries & Std. dev. & 0.1819 & 0.1822
\end{tabular}

Note: The table presents sample moments of ratios of equity in U.S -owned joint ventures to equity in all U.S.owned foreign affiliates. Fast GDP growth countries are those countries growing at least $4 \%$ per annum over 1960-1985; slow GDP growth countries are those growing more slowly than $4 \%$. High R\&D intensity countries are those countries with R\&D/GDP ratios exceeding $0.9 \%$ in 1988 ; low R\&D intensity countries are those with ratios below $0.9 \%$. 
Table 2

U.S. Joint Venture Intensity, 1982

Dependent Variable: Fraction of Total Affiliate Equity in Joint Venture Form

\begin{tabular}{|c|c|c|c|c|c|}
\hline & (1) & (2) & (3) & (4) & $(5)$ \\
\hline Constant & $\begin{array}{c}0.0231 \\
(0.1170)\end{array}$ & $\begin{array}{l}-0.0140 \\
(0.1169)\end{array}$ & $\begin{array}{c}0.2953 \\
(0.1518)\end{array}$ & $\begin{array}{c}0.0068 \\
(0.1382)\end{array}$ & $\begin{array}{l}-0.0427 \\
(0.1097)\end{array}$ \\
\hline $\begin{array}{l}\% \Delta \text { GDP } \\
1960-1985\end{array}$ & $\begin{array}{c}3.8272 \\
(2.1023)\end{array}$ & $\begin{array}{c}3.9988 \\
(2.1090)\end{array}$ & $\begin{array}{l}-2.7171 \\
(2.9588)\end{array}$ & $\begin{array}{l}-0.1649 \\
(3.0127)\end{array}$ & $\begin{array}{l}-0.9755 \\
(2.2285)\end{array}$ \\
\hline $\begin{array}{l}\text { R\&D } \\
\text { Intensity }\end{array}$ & $\begin{array}{c}0.0341 \\
(0.0346)\end{array}$ & $\begin{array}{c}0.0238 \\
(0.0409)\end{array}$ & $\begin{array}{l}-0.2184 \\
(0.0666)\end{array}$ & $\begin{array}{l}-0.1764 \\
(0.0669)\end{array}$ & $\begin{array}{l}-0.1163 \\
(0.0573)\end{array}$ \\
\hline $\begin{array}{l}\text { (GDP growth } \\
\text { R\&D intensity) } \\
\text { Interaction }\end{array}$ & & & $\begin{array}{c}5.6695 \\
(1.5629)\end{array}$ & $\begin{array}{c}4.7523 \\
(1.6517)\end{array}$ & $\begin{array}{c}4.1430 \\
(1.3625)\end{array}$ \\
\hline GDP 1982 & & $\begin{array}{c}0.0132 \\
(0.0134)\end{array}$ & $\begin{array}{c}0.0076 \\
(0.0098)\end{array}$ & $\begin{array}{c}0.0044 \\
(0.0101)\end{array}$ & $\begin{array}{c}0.0032 \\
(0.0081)\end{array}$ \\
\hline Tax 82 & & & & $\begin{array}{c}0.5853 \\
(0.2641)\end{array}$ & $\begin{array}{c}0.5349 \\
(0.2425)\end{array}$ \\
\hline $\begin{array}{l}\text { Ownership } \\
\text { Restrictions }\end{array}$ & & & & & $\begin{array}{c}1.1454 \\
(0.3690)\end{array}$ \\
\hline Adj. $R^{2}$ & 0.0547 & 0.0991 & 0.2468 & 0.2968 & 0.4401 \\
\hline \# Obs. & 40 & 38 & 38 & 34 & 34 \\
\hline
\end{tabular}

Note: The dependent variable is the ratio of equity in U.S.-owned joint ventures to equity in all U.S.-owned foreign affiliates. "\% $\triangle$ GDP, 1960-1985" is real GDP growth between 1960 and 1985 measured at intemational prices. "R\&D Intensity" represents R\&D/GDP ratios in 1988. "GDP 1982" is 1982 GDP measured in $\$ 100$ billion. "Tax ' 82 " is the tax rate applicable to U.S. investors in 1982 (truncated at 34\%). "Ownership Restrictions" is the fraction of U.S. firms indicating that host govemments limit their percentage ownership of local affiliates. The columns report estimated OLS coefficients; White-corrected standard errors are in parentheses. 
Table 3

U.S. Joint Venture Activity by Number of Affiliates and Parents, 1982-1989

Numbers of Affiliates and Parents

$\begin{array}{cccc}\text { Nonbank affiliates of all parents } & 1982 & 1989 & \begin{array}{r}\text { \% Change } \\ (1982-89)\end{array} \\ \begin{array}{ccc}\text { Minority-owned affiliates } \\ \text { Majority-owned affiliates }\end{array} & 2,868 & 2,516 & -12.27 \\ \text { Total affiliates } & 14,589 & 15,654 & 7.30 \\ & 17,457 & 18,170 & 4.08\end{array}$

All parents of nonbank affiliates

$\%$ Change

Parents with minority-owned affiliates 778

1989

(1982-89)

Parents with majority-owned affiliates

1,931

689

$-11.44$

Total parents

2,138

2,065

6.94

2,209

3.32

Note: The top panel reports numbers of minority-owned and majority-owned foreign affiliates of U.S. firms in 1982 and 1989. The bottom panel reports numbers of U.S. parent firms with minority-owned and majorityowned foreign affiliates in 1982 and 1989. Column entries in the bottom panel do not sum to total due to parent firms with both minority-owned and majority-owned affiliates. 
Table 4

Nonparametric Measures by Ownership Status and Tax Rate, 1982-1989

$\% \Delta$ Affiliate Equity, $\Delta$ Royalty Payments, $\Delta$ Leverage Ratio 1982-1989

\begin{tabular}{|c|c|c|c|}
\hline & \multicolumn{2}{|c|}{ Low Tax Countries } & \multirow[t]{2}{*}{ High Tax Countries } \\
\hline \multirow{3}{*}{ Joint Ventures } & Mean & 0.5377 & \\
\hline & Median & 0.2973 & 0.5816 \\
\hline & Std. dev. & 1.1909 & 4.1848 \\
\hline$\% \Delta$ Equity & Mean & 1.2922 & 0.5324 \\
\hline \multirow[t]{2}{*}{ Majority Owned } & Median & 1.1687 & 0.5352 \\
\hline & Std. dev. & 0.8424 & 1.3717 \\
\hline \multirow{3}{*}{ Joint Ventures } & Mean & -0.0003 & -0.0031 \\
\hline & Median & 0.0000 & 0.0000 \\
\hline & Std dev. & 0.0094 & 0.0099 \\
\hline$\Delta$ Royalty & Mean & 0.0035 & 0.0112 \\
\hline \multirow[t]{2}{*}{ Majority Owned } & Median & 0.0037 & 0.0052 \\
\hline & Std. dev. & 0.0082 & 0.0149 \\
\hline \multirow{3}{*}{ Joint Ventures } & Mean & 0.0738 & -0.0302 \\
\hline & Median & 0.0570 & -0.0215 \\
\hline & Std. dev. & 0.2190 & 0.1636 \\
\hline$\Delta$ Leverage & Mean & -00223 & - 00101 \\
\hline \multirow{2}{*}{ Majority Owned } & Median & $\begin{array}{l}-0.0223 \\
-0.0346\end{array}$ & $\begin{array}{l}-0.0106 \\
-0.0057\end{array}$ \\
\hline & Std. dev. & 0.1082 & 0.1411 \\
\hline
\end{tabular}

Note: The table presents moments of percentage changes in equity, changes in royalty payments, and changes in leverage ratios for joint ventures and majority-owned affiliates in low tax and high tax countries between 1982 and 1989. Low tax countries are those countries that have tax rates lower than $33 \%$ in 1982; high tax countries are those with tax rates greater than $33 \%$. There are 21 observations for joint ventures in low tax countries, and 23 in high tax countries. There are 22 observations for majority owned ventures in low tax countries, and 23 in high tax countries. 


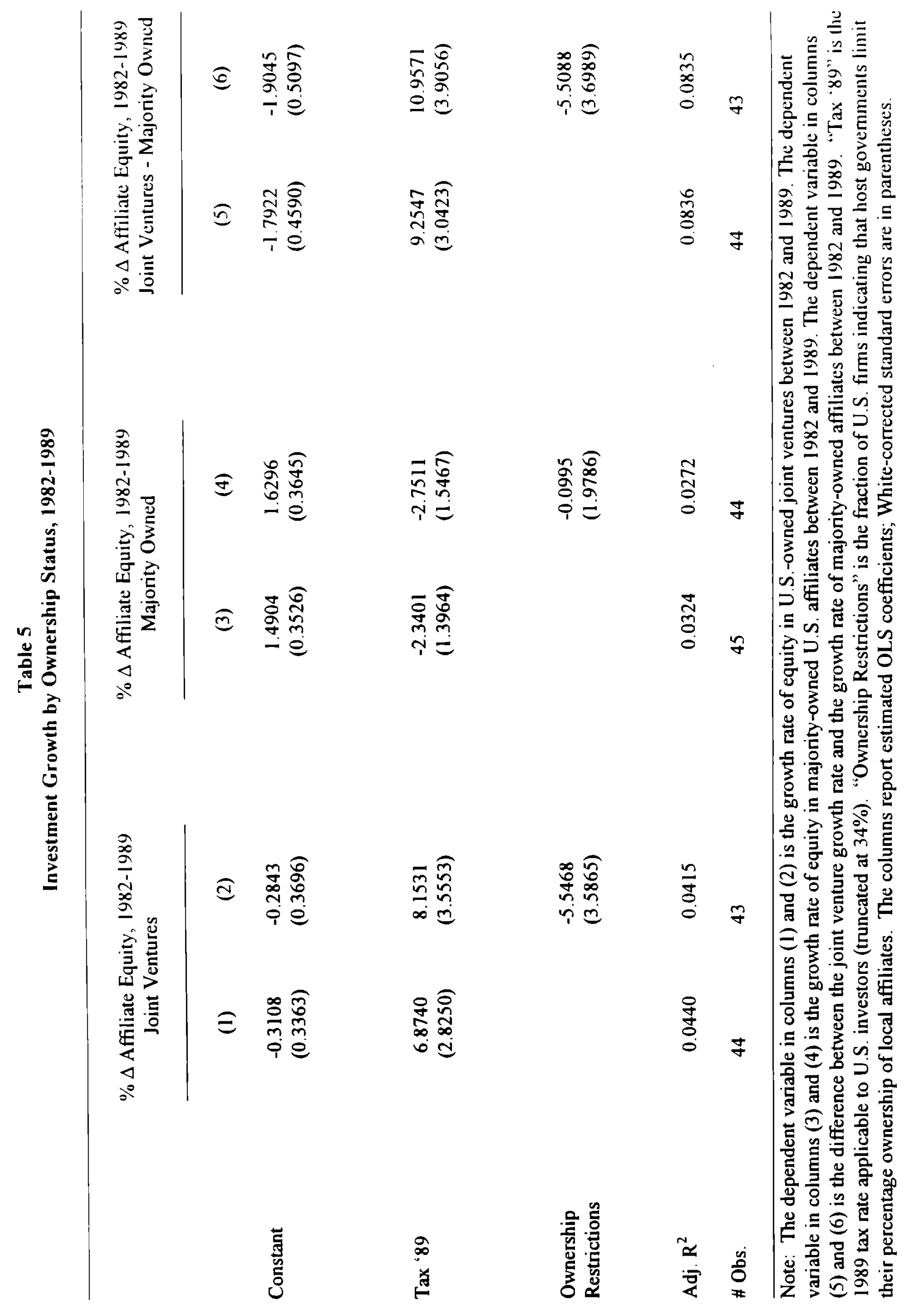




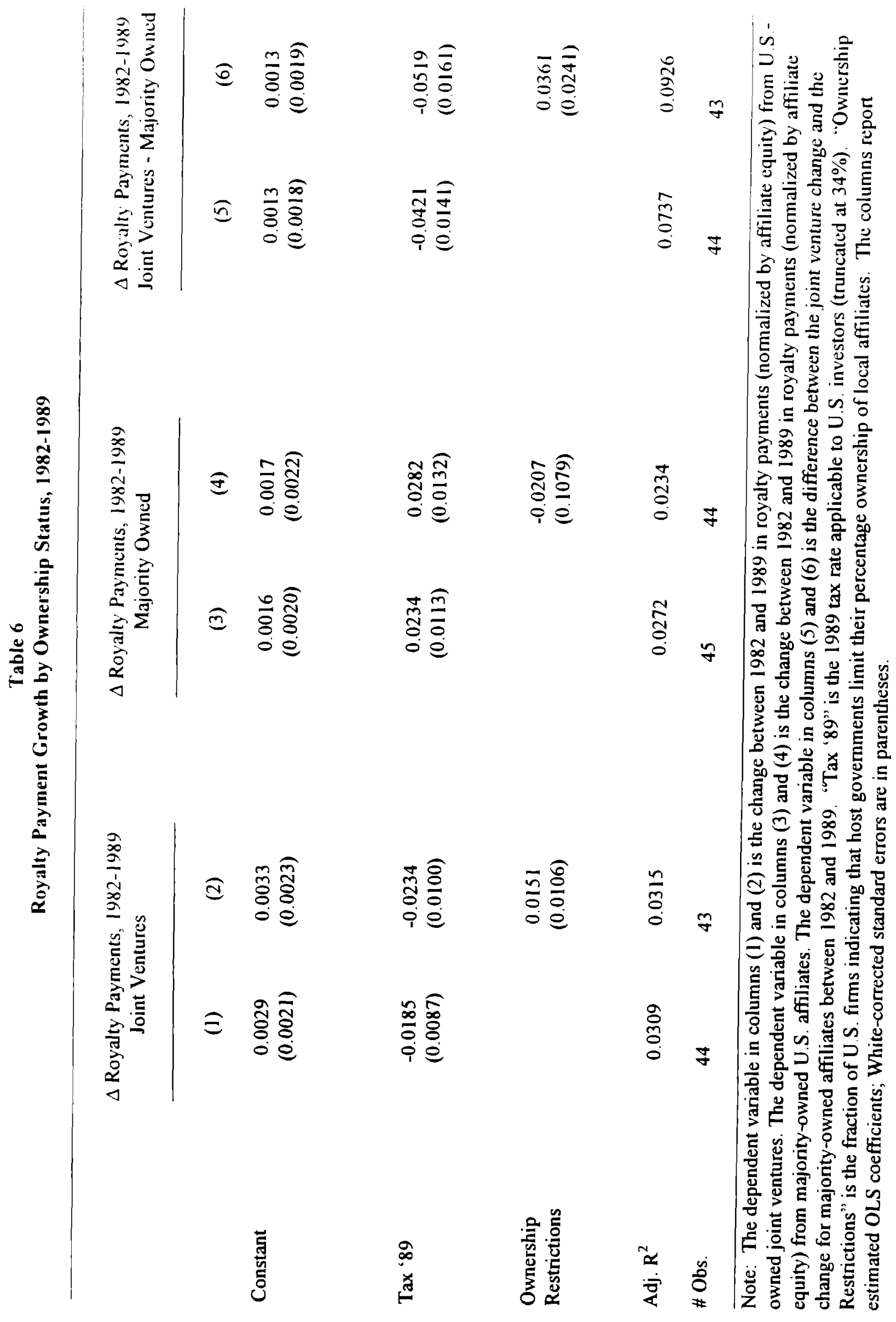




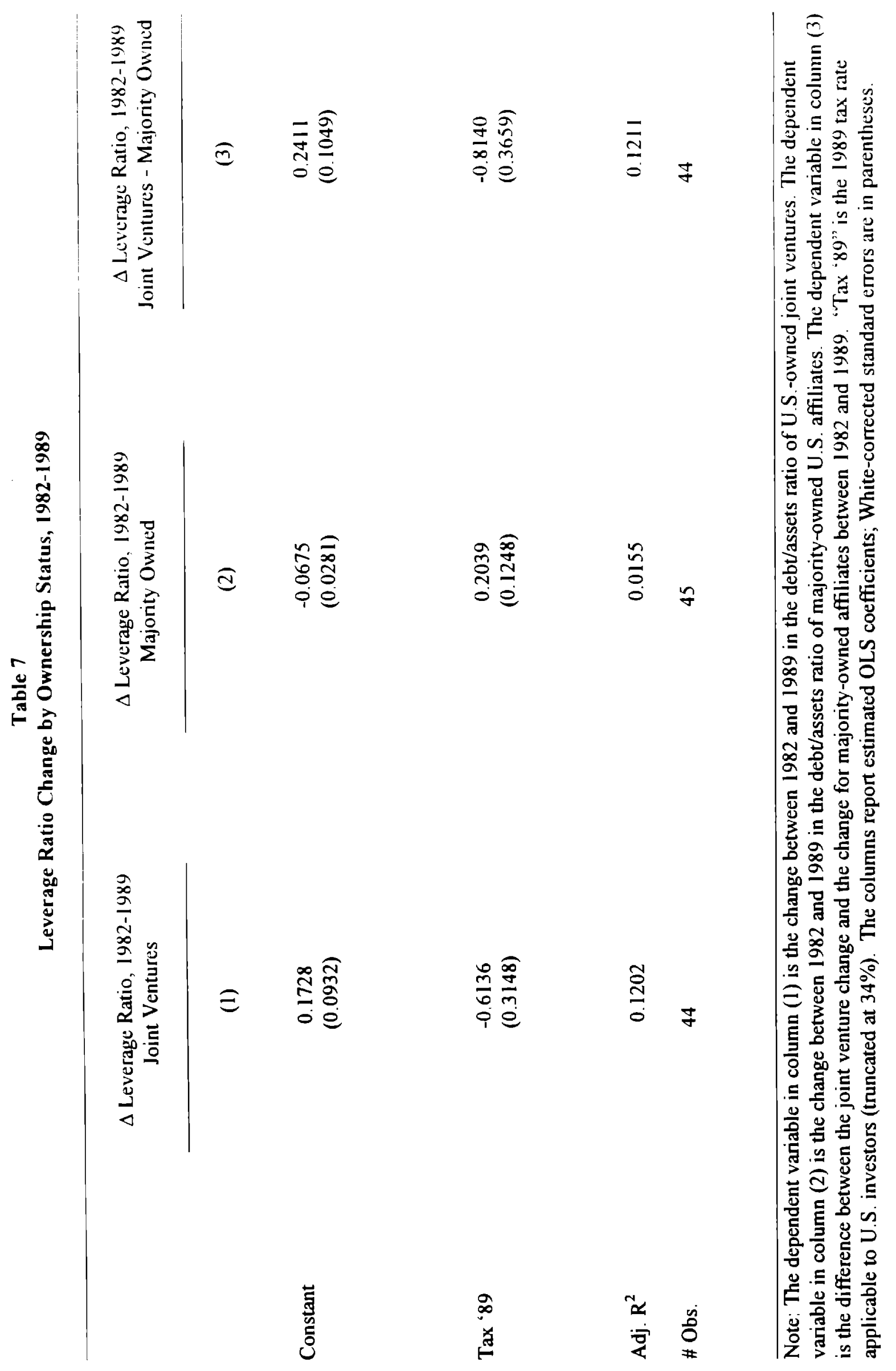


Fraction of Total Affiliate

Equity in Joint Venture Form, 1982

$\% \Delta$ GDP, 1960-1985

$$
0.0446
$$

0.0174

R\&D Intensity

1.1700

0.9152

40

(GDP growth $*$ R\&D intensity)

0.0523

0.0459

Interaction

GDP 1982

Tax 82

$\operatorname{Tax} ' 89$

0.2500

0.1203

Ownership Restrictions

0.0603

0.1051

$\% \Delta$ Affiliate Equity, 1982-1989 Joint Ventures

Majority Owned

0.9039

1.1946

$\Delta$ Royalty Payments, 1982-1989

Joint Ventures

$-0.0017$

0.0096

44

Majority Owned

0.0074

0.0126

45

Joint Venture - Majority Owned

$-0.0093$

0.0164

44

$\Delta$ Leverage Ratio, 1982-1989

Joint Ventures

0.0194

0.1969

44

Majority Owned

$-0.0163$

0.1248

45

Joint Venture - Majority Owned

0.0376

0.2604

44

Note: "\% $\triangle$ GDP, 1960-1985" is real GDP growth between 1960 and 1985 measured at international prices. "R\&D Intensity" represents R\&D/GDP ratios in 1988. "GDP 1982" is 1982 GDP measured in \$100 billion. "Tax ' 82 " is the 1982 tax rate applicable to U.S. investors (truncated at $34 \%$ ); "Tax ' 89 " is the corresponding 1989 tax rate. "Ownership Restrictions" is the fraction of U.S. firms indicating that host governments limit their percentage ownership of local affiliates. Affiliate equity, royalty, and leverage variables are country-level aggregates reported in the 1982 and 1989 BEA Benchmark Surveys. "\% $\%$ Affiliate Equity, 1982-1989" is the growth rate of equity in U.S. -owned joint ventures, majority-owned U.S. affiliates, and the difference between these rates, between 1982 and 1989. " $\Delta$ Royalty Payments, 
1982-1989" is the change between 1982 and 1989 in royalty payments (normalized by affiliate equity) from U.S. -owned joint ventures. majority-owned U.S. affiliates, and the difference between these changes. "I Leverage Ratio. 1982-1989" is the change between 1982 and 1989 in the debt/assets ratio of U.S. -owned joint ventures. majority-owned U.S. affiliates, and the difference between these changes. 
Appendix Table 2

Tax Rates

Country and Tax Rate, 1989

\begin{tabular}{|c|c|c|c|}
\hline Argentina & 0.33 & Japan & 0.50 \\
\hline Australia & 0.37 & Luxembourg & 0.16 \\
\hline Austria & 0.30 & Malaysia & 0.40 \\
\hline Bahamas & 0.00 & Mexico & 0.35 \\
\hline Belgium & 0.23 & Netherlands Antilles & 0.05 \\
\hline Bermuda & 0.02 & Netherlands & 0.17 \\
\hline Brazil & 0.42 & Panama & 0.03 \\
\hline Canada & 0.37 & Peru & 0.35 \\
\hline Chile & 0.33 & Philippines & 0.35 \\
\hline Colombia & 0.30 & Portugal & 0.29 \\
\hline Denmark & 0.36 & Singapore & 0.11 \\
\hline Ecuador & 0.46 & South Africa & 0.50 \\
\hline Finland & 0.38 & South Korea & 0.44 \\
\hline France & 0.39 & Spain & 0.25 \\
\hline Germany & 0.37 & Sweden & 0.37 \\
\hline Greece & 0.40 & Switzerland & 0.08 \\
\hline Hong Kong & 0.14 & Taiwan & 0.14 \\
\hline India & 0.50 & Thailand & 0.25 \\
\hline Ireland & 0.02 & Turkey & 0.48 \\
\hline Israel & 0.29 & United Kingdom & 0.28 \\
\hline Italy & 0.43 & U.K. Islands & 0.01 \\
\hline Jamaica & 0.08 & Venezuela & 0.38 \\
\hline
\end{tabular}

Source: Authors' calculations based on data in Price Waterhouse (1989) and BEA (1992). 


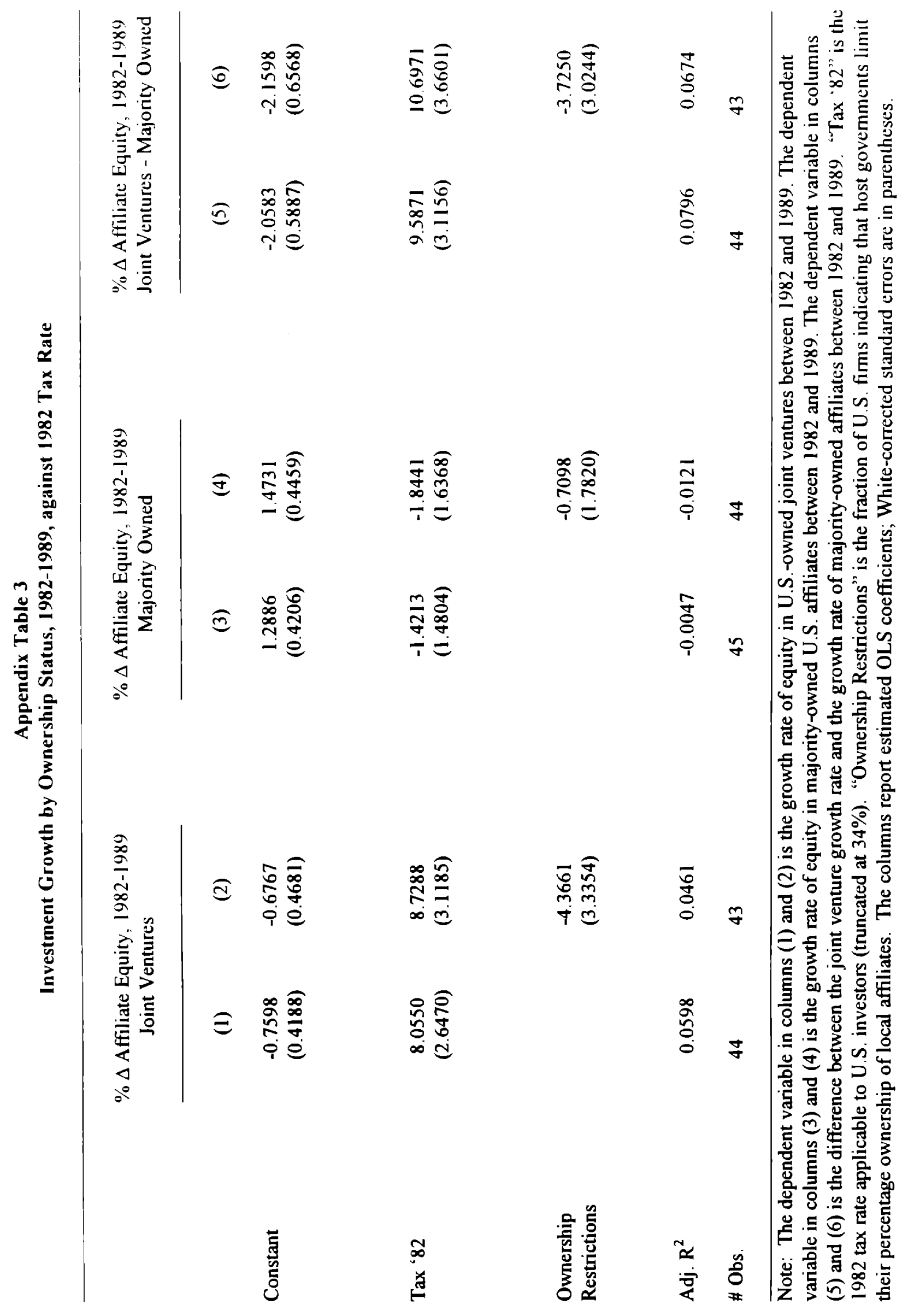




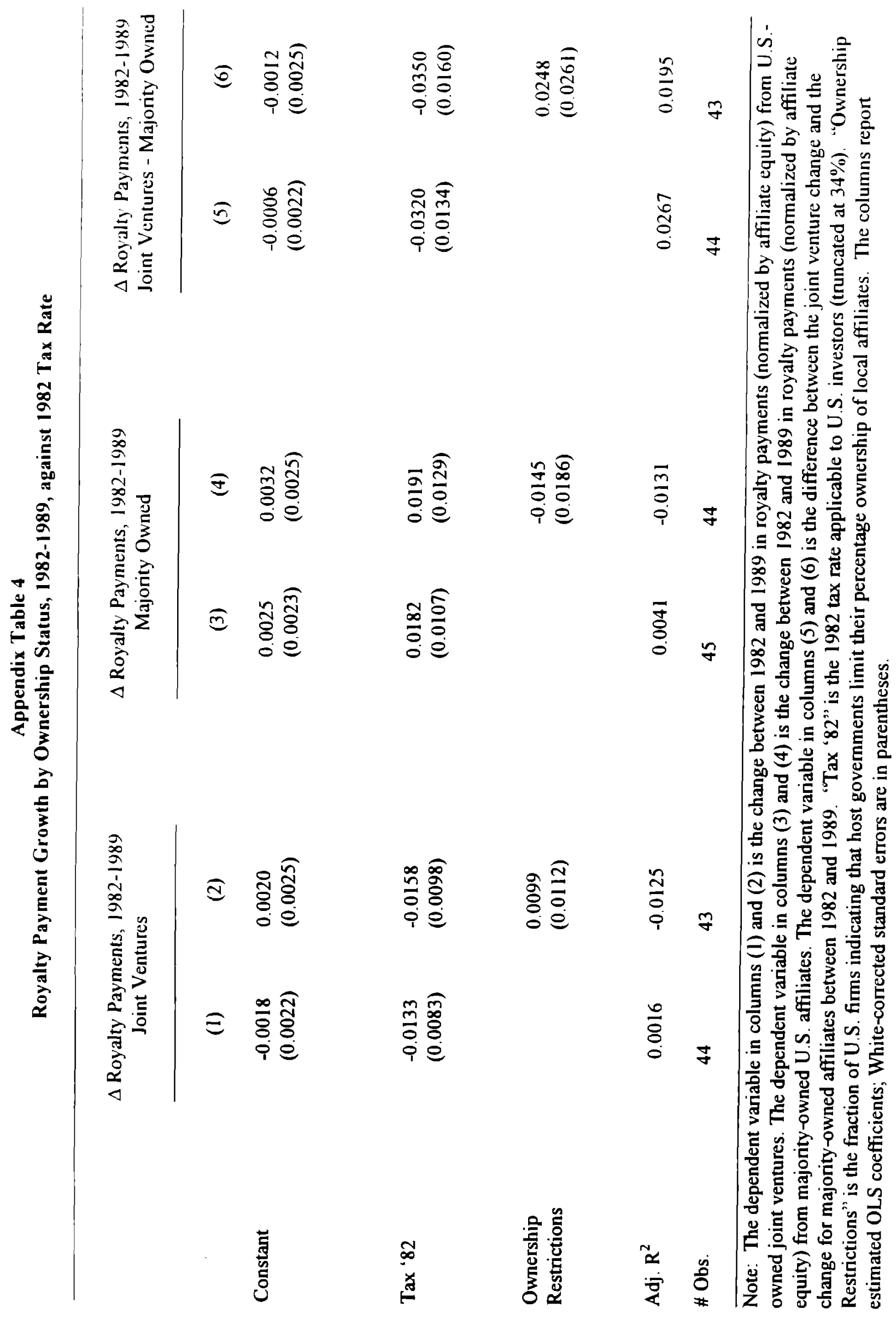




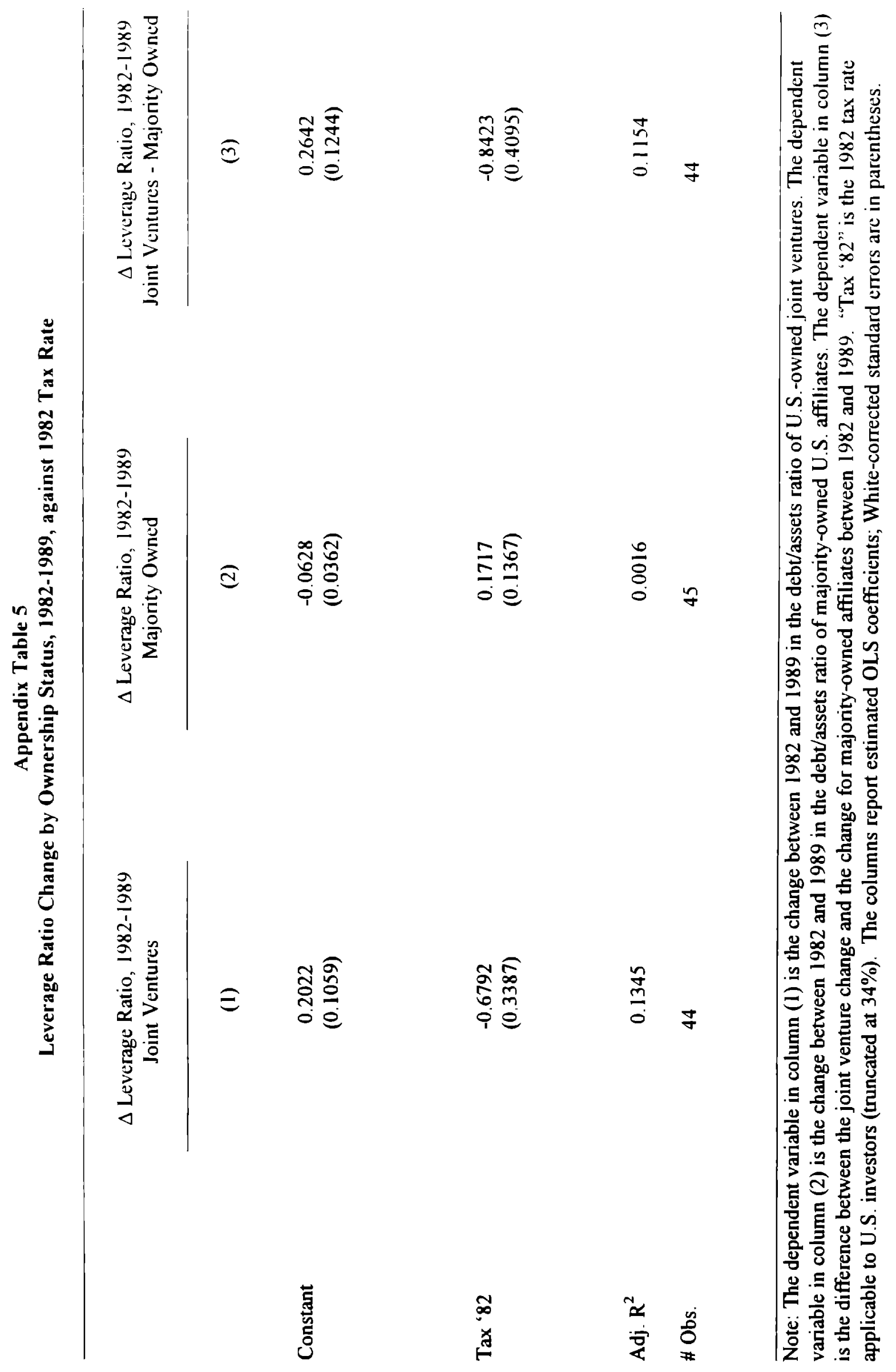

